Tone Sofie Aglen

Statsviter, kommentator i Adresseavisen

Foto: Jens Søraa/Adresseavisen

\title{
Gåten «Generasjon perfekt»
}

\author{
Nedslående tall om ungdommens \\ psykiske helse etterlater et viktig \\ spørsmål: Er det mennesket som \\ er sykt eller er det samfunnet som \\ er sykt?
}

Stress og lette psykiske lidelser er for lengst blitt folkesykdommer. Halvparten av befolkningen i Norge har psykiske plager eller lidelser i løpet av livet. Problemene ser ut til å ha smittet over på dagens ungdomsgenerasjon, hvor underlig det enn er. De unge er flinke og fornuftige. Ikke drikker de og ikke skulker de. De trener på treningsstudio og de gjør mer lekser enn vi noen gang gjorde. Tagging har de knapt hørt om. Dagens ungdom er så skikkelige at det nesten er litt kjedelig. Derfor kalles de gjerne Generasjon perfekt. Men medaljen har også en bakside.

Det står åpenbart verre til med sjelen enn med kroppen. Ulik forskning forteller den samme historien - dagens ungdom strever med sin psykiske helse. Mange rapporterer at de er ulykkelige, triste og ensomme. Den siste Ungdata-unders $\varnothing$ kelsen viste at mellom $20 \%$ og $40 \%$ av de unge i Trondheim er plaget med bekymringer og søvnproblemer. Trønderne er neppe annerledes enn annen ungdom. Selvskading forekommer stadig oftere. Mer enn én av fem oppgir at de har fors $\varnothing k t$ å skade seg selv.

Dette er en trend som er vanskelig å forstå. Sett ut fra alle tenkelige objektive kriterier har dagens unge det bedre enn noen gang. Da er det lettere å forstå at stress ikke lenger er forbeholdt dobbeltarbeidende småbarnsmødre og topp- ledere med Birken-ambisjoner. Stadig flere unge er stresset. $30 \%$ av svenske 16-åringer er så stresset at det kan klassifiseres som alvorlig. Forskere tror den samme tendensen gjelder norsk ungdom. Forbløffende mange er det vi ville ha kalt flinke og vellykkede.

Vi i mediene skriver mye og gjerne om disse fenomenene, og det er unektelig et tema som engasjerer. Jeg får ofte tilbakemelding fra foreldre, lærere og andre voksenpersoner som kjenner seg igjen. Jeg savner imidlertid flere helsefaglige vurderinger. Hva betyr det i realiteten at en så stor andel av ungdommene oppgir at de nedstemt og stresset? Tallene som presenteres i ulike unders $\emptyset$ kelser og medieoppslag er dramatiske. Jeg savner imidlertid en dypere forståelse av hvordan vi kan forstå tallene. Står det så dårlig til med den psykiske folkehelsen som det ser ut? Har vi fått en lavere terskel for å rapportere psykisk smerte? Eller er de nedslående tallene rett og slett en bieffekt av å være menneske?

Det er lett å ty til forklaringer som peker på samfunnet. Det er ikke vanskelig å se at presset på å være vellykket er en viktig stresskilde. Alt var ikke bedre $f \varnothing r$, men presset på de unge var nok samlet sett lavere. Om du var en ener på fotballbanen eller flink på skolen, du dugde. I dag skal du være både pen, smart og veltrent. Karakterboken skal fylles med seksere og fritiden med aktivitet. Mange knekker i jakten på det perfekte liv. Men livet var neppe en dans på roser i tidligere tider heller.

Stress kan også knyttes til tilgjengelighet. 24-timerssamfunnet har gitt oss sosial jetlag. I min barndom var dagen over når uret overtok TV-skjermen. Klokken 2300 var det slutt på moroa. Nå er det ikke bare fjernsynet som tilbyr underholdning døgnet rundt. Meldinger tikker inn. Nyheter legges ut. Facebook oppdateres. Det gjør også Snapchat, Instagram, Twitter og Kik. Internett sover aldri. Sliten blir den som vil ha med seg alt. Samfunnsviterne forsker på hva dette gjør med oss. Sosiologen Aksel Tjora gjennomførte et forskningsprosjekt hvor 14 personer prøvde et liv uten internett i tre uker. En tydelig effekt var at de ble mer konsentrert, rolige og avslappet av offlinelivet. Det finnes helt sikkert også helsemessige konsekvenser av å være pålogget døgnet rundt.

Hva som blir igjen av den mye omtalte samhandlingsreformen er ikke godt å se. En av intensjonene bak reformen er å satse på forebygging. Sykdom og plager skal behandles på lavest mulig nivå. Helsesøstre forteller om lite ressurser til å hjelpe ungdommer med psykiske problemer på en god nok måte. De største kommunene i Norge har færre ansatte i skolehelsetjenesten enn det Helsedirektoratet anbefaler. Det virker åpenbart fornuftig å styrke skolehelsetjenesten og andre lavterskeltilbud for ungdom. Jeg savner imidlertid kunnskap om hva som egentlig hjelper.

Alle har vi perioder der vi ikke mestrer hverdagens utfordringer. Det er slett ikke sikkert alt hører hjemme på legenes bord. Kanskje er det bivirkninger av samfunnet vi har skapt, og de lar seg ikke behandle medisinsk. Men debatten må ta oss nærmere svaret på hva som plager dagens unge.

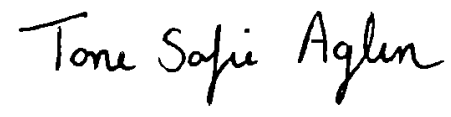

